\title{
Editorial
}

\section{心筋 $\mathrm{Na}^{+}$チャネル病：10年間の進歩と末来}

北海道大学大学院医学研究科循環病態内科学 蒔田直昌

不整脈の一つの病因として, イオンチャネルの遺 伝的異常があげられることは, 現在ほほ周知の事実 である、しかし，それが最初に立証されたのは，先 天性 QT 延長症候群 (LQTS) の原因遺伝子の同定と 機能解析に関する論文が相次いで発表された, 今か ら 10年前の 1995 年である.これらの研究は, 長年 蓄積された不整脈の臨床研究とイオンチャネルの基 䃈研究の間に有機的な橋渡しとなって, 不整脈の病 態を単一チャネルレベル・遺伝子レベルで解明する 研究をさらに推進させた。もちろんこれらの研究の 基盤として, イオンチャネルの一次構造をいち早く 明らかにした沼らや，パッチクランプ法を開発した Neher \& Sakmann らをはじめとする, 多くの先達 の偉業があることは言うまでもない。

膜電位依存性 $\mathrm{Na}^{+}$チャネルは, 神経・筋などの興 奮性細胞において, 活動電位の急速な立ち上がりを 担うイオンチャネルである. 現在, $\mathrm{Na}^{+}$チャネルに は 9 つの $\alpha$ サブユニットと 4 つのサブユニットの遺 伝子の存在が知られているが，これらの遺伝子異常 による疾患を「 $\mathrm{Na}^{+}$チャネル病」と総称する。そのう ち最も早くから研究が進められたのは, 骨格筋 $\mathrm{Na}^{+}$ チャネル $(S C N 4 A) て ゙$ その研究成果は, 不整脈 (心 筋 $\mathrm{Na}^{+}$チャネル：SCN5A) やてんかん（脳 $\mathrm{Na}^{+}$チャネ ル：SCN1A・SCN2A)などの骨格筋以外の $\mathrm{Na}^{+}$チャ ネル病の病態解明の規範となった。

SCN5A に変異を有する「心筋 $\mathrm{Na}^{+}$チャネル病」とし て最も著名なのは 3 型先天性 LQTS (LQT3) と Brugada症候群であるが, そのほかにも家族性心臓 ブロック・洞機能不全症候群・洞停止・乳幼坚突然
死症候群・房室ブロックなどの先天性不整脈があげ られる. 心筋 $\mathrm{Na}^{+}$チャネル病の病態は, 変異チャネ ルの機能特性によって大きく二分することができ る. LQT3変異チャネルは, 不活性化が障害されて いるため, 細胞内への $\mathrm{Na}^{+}$流入が遷延し (gain-offunction), それによって活動電位持続時間 (すなわ ちQT 時間) が延長する.一方, Brugada症候群など の変異チャネルでは逆に, $\mathrm{Na}^{+}$電流が減弱ないし消 失する (loss-of-function). Brugada症候群のST 上昇 と VFは, 減弱した $\mathrm{Na}^{+}$電流によって, 対抗する一 過性外向き電流 $\left(\mathrm{I}_{\mathrm{t}}\right)$ が相対的に増加し, 貫壁性の電 位勾配や心筋内の不均一性が増強することによって 起こると考えられている. しかし, Brugada症候群

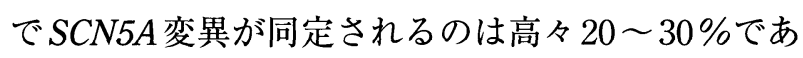
り, 主たる原因遺伝子は別にあると推測される。ま た，無症状でありながら典型的な Brugada症候群型 の心電図を示す「無症候性 Brugada症候群」は, 上述 した有症候性Brugada症候群と比較して, 病態や予 後にどのような違いがあるかは解明されて抢らず， 今後の研究が期待される.

QT 延長症候群や Brugada 症候群では, 発端者と 同じ変異をもちながら心電図は正常という家族がし ばしばみられる(incomplete penetrance)。また $S C N 5 A$ は心房・心室・刺激伝導系に広く分布するの に, 心房特異的な表現型や刺激伝導系の選択的な障 害を示すことがある，最近では，薬剤・心筋症・心 筋虚血などの後天的な要因によって発生する致死性 不整脈にも，イオンチャネルの遺伝的要因が関与し ているという報告もある。これらの事実は, $\mathrm{Na}^{+}$チャ 
ネル病の臨床像は $S C N 5 A$ 変異のチャネル特性で完 全に説明できるのではなく, 心筋に存在する様々な 機能分子上の遺伝子多型や不顕性変異が, SCN5Aの 機能を修飾する「遺伝的修飾因子」となっている可能 性を示唆する.

先天性不整脈のような比較的まれな疾患に関する
研究を, 日常的によく遭遇する二次性不整脈などに あてはめることによって, 不整脈が起きやすい「体 質」を分子生物学的に明らかにし，将来的には，不 整脈の発症前からそれに対処することで, 突然死を 減少させることが望まれる. 